\title{
Implementation of research activities by mobile technologiyi as a method to forming cognitive independence of pupils
}

\author{
T. I. Hranovska \\ H. S. Skovoroda Kharkiv National Pedagogical University, Ukraine
Corresponding author. E-mail: taniya20gran@gmail.com
}

Paper received 17.01.20; Accepted for publication 03.02.20.

\section{https://doi.org/10.31174/SEND-PP2020-219VIII87-03}

\begin{abstract}
The article analyzes the importance of performing research activities in the study of natural subjects. It is determined that performing research activities promotes the development of research skills, which are the keys to successful research. Conducting experimental and research activities contribute to the creation of a scientific and creative atmosphere among the participants of the educational process, which positively influences the development of cognitive independence of pupils.

The paper paid attention to the existence of some mobile digital sensors in mobile technologies, mobile applications, experimental laboratories and analyzes their research capabilities, in particular through the connection of hypersensitive digital sensors that allow performing experiments with high accuracy of results and complete safety for pupils.

Keywords: research activity; cognitive independence; mobile applications, digital sensors, mobile labs.
\end{abstract}

Introduction. The informatization of society directly influences the educational process, which predetermines the use of various ICTs in the classroom. A modern school needs the introduction of new innovative and technological approaches that will enable pupils to expand their subject knowledge independently. With the help of ICT, a teacher can give studying the material in an accessible and entertaining way, but the important task of modern education is to teach an independent person for lifelong learning. Encouraging pupils to dive into cognitive activity is possible if only this activity is important for the pupils. Such activities could provoke cognitive interest and a desire to achieve a particular result. The authors believe that pupils may be interested in participating in research activities that they can do with personal gadgets. These include digital technologies. Particular attention should be paid to the potential of mobile technology for performing research activities, which is important for pupils' cognitive independence development.

Literature review. Conducting research activities should be aimed at creating a scientific and creative atmosphere, the purpose of which is the formation of cognitive interest as a promoting factor for participation in research activities, namely, conducting an experiment and analyzing the obtained results.

The problem of applying the research activity in the study process is not a new one. The following prominent teachers studied this issue at different periods: Ia. Komensky, V. Sukhomlynskyi, K. Ushynskyi, S. Rubinstein, G. Altshuller, M. Montessori, R. Owen, F. Frebel, etc. However, nowadays methods and research tools changed a lot. Previously, research was conducted as part of the observation of record directories or experiments in reagent laboratories. But nowadays the scope of pupils' research significantly expanded due to the use of modern laboratory equipment (if any), computer diagnostics, and digital sensors.

The scientific works of domestic scientists [1] devoted to the research of the practical use of some mobile sensors and mobile applications in the study of natural and mathematical subjects. Other scientists [2], [3], [4] investigated the analysis and features of using mobile applications and sensors in physics lessons.
The analysis of literary sources showed that research activity organization has established theoretical prerequisites for pupils activity. The important research skills, which are the key to successful research formed in the process of research conducting.

H. Yagenskaya names pupils' research skills the readiness to perform intellectual and practical research manipulations, based on the theoretical knowledge and life experience while formulating the purpose, creating the conditions, choosing the means of activity necessary for the investigation of processes and phenomena [5]. Research skills are a complex phenomenon that includes the knowledge and skills to combine the ability for creative action [6]. The research skills forming in pupils is a complex and long-lasting process. To be sure it is possible to acquire practical skills only with direct participation in research work, but under the teacher's supervision who has to control the process and teach how to use the equipment and devices.

The purpose of the study is to analyze mobile technologies using, in particular sensors of mobile devices for research activity as a method of cognitive independence forming in primary school pupils.

Theoretical sub-chapters. The presence of the experimental part in the natural sciences is a promising basis for research activities and has a significant educational potential for the specific skills formation, which leads to increased interest in pupils to study and to develop positive steps for participation in cognitive activity.

Most of Ukrainian school laboratories do not have sufficient material base to experiment. That is why it is advisable to use various ICTs to increase activity in the classroom and increase interest in the study process. In teaching natural sciences, it is very difficult to form an aggregate picture of the course of various processes and phenomena and to generate cognitive interest without using practical activity and illustrative material. To check the theoretical data by experiment and practical thinking is in modern pupils'nature. Typically, pupils use the Internet to find the truth and get answers instantly. Such a feature of modern teenagers promotes the formation of cognitive autonomy, based on the independent search for 
information, the study of material and the desire to participate in practical activities [7, p.267].

An important point is that during the experiment, a large number of processes are reproduced, ie a series of sequential research actions. The study of physical or chemical phenomena first occurs theoretically then there is a need to check them. However, after the experiment, there is a need to explain the results theoretically. That is, the theory must be confirmed or refuted experimentally. In addition to school laboratory and practical work or conducting demonstration experiments, there is a need for scientific research, in the form of projects or other competitive works. But modern school faces difficulties in organizing such pupils' activities. This is due to several reasons: the lack of equipment in the chemical, physical or biological classrooms and the lack of safe conditions for experiments, the lack or absence of reagents, etc. At the same time, the involvement of pupils in conducting experiments leads to a more conscious understanding of the educational material, promotes increasing interest in the subject, the thinking development, curiosity, and broadening of outlook [8].

Research work can be done on mobile gadgets without special accessories and are safe for pupils. They include sensors in smartphones and tablets, as well as mobile applications. Most modern smartphones have the following sensors: accelerometer, gyroscope, light sensor, proximity sensor, barometer, temperature sensors, sound sensor, camera, compass, a satellite navigation system (GPS), etc. [9].

The scientific publications mostly paid attention to the following mobile gadgets sensors: accelerometer, gyroscope, microphone, location, and proximity sensor, GPS, light sensor, etc. [10].

The emergence of new brands of mobile gadgets encourages developers to improve and diversify their product capabilities. Thus capabilities of mobile gadgets increase and multifunctional mobile application development. This includes applications for measuring temperature, pressure, and humidity. For example, the mobile application "Scientific journal" [11] is a digital diary for pupils' research. Its functionality includes: measuring light, sound frequency, accelerating movement, measuring the direction of motion with a compass, as well as the magnetic field measuring. The graphs plotted based on measurements and it is possible to annotate indicators or record the necessary information, which is an important point in conducting research.

For physics and chemistry research, an important indicator is a temperature that can be measured using mobile technologies. Mobile applications for temperature measurement are various. The majority of mobile thermometers measure indoor and outdoor temperatures have a switch of temperature scales (Celsius and Fahrenheit). For example, "Thermometer $++"$ is a combined application that measures temperature, humidity, and pressure based on location. It can be used for research on geography and biology in nature [12].

The "Thermometer Smart Family" mobile application is designed to measure the temperature of the body, liquids, gases and bulk mixtures, however, it requires the connection of a specially designed RELSIB WT50 thermometer that transmits data via Bluetooth. The temperatures range from -30 to +70 degrees Celsius $(-22$ to +158 degrees Fahrenheit) can be measured with this app. There is a fixation of the minimum and maximum values of the temperature from the beginning and the end of the measurement, which is important in research in chemistry, for example in the study of thermodynamic processes. The obtained data can be displayed as a graph, and the results stored in measurement history and sent to e-mail [13].

The "Qualità dell'aria" app [14] allows the measurement of air quality and content. According to the developers, the capabilities of the application allow monitoring the weather conditions anywhere, as well as checking the air content online in all parts of the world.

"AWS Weather Station Home Barometer \& Hygrometer" is an application for measuring pressure, humidity and temperature, as well as wind speed. Measurements can be carried out indoors and outdoors, and other indicators can be measured using a GPS sensor [15].

One of the main attributes of smartphones is the camera, which pupils actively use for photos and videos, without using other functions. The main element of the digital camera is a light-sensitive matrix, which is designed to convert the projected optical image into an analog electrical signal.

The smartphone camera can be used for pupils' research. For geography study, pupils can take panoramic and landscape photos by "GoogleMaps" [16], create touristic routes and mark vacation spots, museums, exhibitions, various geographic objects, etc. Mobile applications for bird and plant recognition can be used for biology research. "Birds of Ukraine" mobile app [17] is an ornithological identifier by a photo that contains 428 species of modern ornithofauna of Ukraine. One can exactly determine the kind of bird by taking a photo of it or recording its singing.

The "PlantNet Plant Identification" [18] and "Flora Incognita - automated plant identification" [19] applications allow identifying plants and classify them by specific characteristics.

"INaturalist" [20] is one of the most popular mobile applications for nature study. Its functionality includes not only the identification of plants and animals but also the fixation of uploaded photos with the location spots to help scientists to track the areas of animals and plants for their protection.

Such applications help to create educational projects to determine the types of plants of a certain region, etc. In our opinion, the use of smartphones for such work will be not only interesting but also informative for pupils. After all, an important point in cognitive activity is the independent observations and experiments that form research skills.

It is possible to perform chemical experiments by reading graphical information through photo processing using the camera. To do this use the "Color Grab (color detection)" mobile app [21], which determines the object's color by a smartphone camera (H-value) and recognizes it through the color model (HSV), based on three color characteristics: Hue, Saturation and Value (Brightness). Thus, light refraction can be investigated and the concentration of colored solutions can be determined [22]. 
It is necessary to plot diagrams or dependency graph in a research work based on performed measurements. There are some mobile applications aimed at this purpose including "Chart Wizard" [23], in which one can select the type of chart, set the necessary parameters and output data in the right form.

If the job requires more complex calculations (average value, sample size, maximum and minimum values, sum, difference, standard deviation, etc.) before plotting dependency graphs, it is necessary to apply the app for statistical calculations "Statistics Calculator Pro" [24].

It is important to check the accuracy of apps in comparison to real devices before using them in research work, as smartphone sensors can produce minor errors. Some developers of mobile applications even point out in the product description how to fix sensors to increase measurement accuracy.

There are also a large number of mobile labs that include a set of high precision devices and digital sensors with high accuracy designed specifically for experimental activity at educational institutions and beyond.

These include "LabQuest 2" a standalone highresolution touchscreen sensor, Wi-Fi or Bluetooth wireless connection with a mobile phone or tablet [25].

The ability to connect a variety of measurement sensors (temperature, humidity, pH, etc.) allow researching chemistry with high accuracy in various aggressive environments.

"PASCO Scientific" [26] is a mobile laboratory that includes: digital sensors (carbon dioxide, oxygen, $\mathrm{pH}$, colorimeter, steel probe for a temperature sensor, etc.), demonstration and laboratory equipment for experiments. The laboratory has wide opportunities for practically oriented training and involvement of each pupil in the experimental activity, it allows performing the following studies in chemistry: purification of contaminated salt, oxygen content, and properties determination, carbonate recognition, etc.

"LabDisc" [27] is a portable mobile device for data logging, a laboratory that is placed on the palm. These unique, multi-touch mobile devices are destined for different research. «LabDisc Enviro» was developed for experiments in the natural sciences. It is possible to study the acidity of rainwater, turbidity, quality; to measure temperature changes during the day; heat absorption, etc with the help of this device. "LabDisc Gensci" laboratory with a multisensor recorder for electrical current measuring, pH solutions, exothermic reactions, etc. "LabDisc BioChem" is a laboratory with a multisensory data logger for biology and chemistry experiments and "LabDisc Physio" in physics.

Such mobile laboratories will be useful for pupils and will encourage them to participate in research activities. It will contribute to the formation of cognitive interest in the study of natural subjects. Competition work on physics, chemistry, biology, and participation in educational projects that are currently relevant is impossible without using special equipment, which makes such laboratories very important in the educational process.

Results and discussions. Performing laboratory and practical work by pupils, workshops in natural disciplines is an independent process that promotes a creative approach to performing certain manipulations. Laboratory experiments teach pupils to be researchers; they reinforce certain skills in work with chemical or physical laboratory equipment. During the research, pupils learn to analyze processes or phenomena, to classify research objects, to make calculations, to record research results correctly, and to draw the conclusion. It is interesting to them not only to observe the process of the reaction but to study the peculiarities of the processes. They seek information about the phenomena that affect the data transformation and try to explain them.

Conclusions. The use of mobile applications and sensors will allow pupils to immerse themselves in research activities to learn how to use measuring devices and to develop research skills that will be necessary for them in future study and own needs realization. Mobile laboratories with digital sensors provide wide opportunities to carry out research works on natural sciences and participate in project activities, which is now a relevant and promising area of pupils' creativity. The opportunity to participate actively in the experimental activities contributes to the development of pupils' cognitive independence.

\section{REFERENCES}

1. Skrypka H.V. Vykorystannia mobilnykh dodatkiv dlia provedennia navchalnykh doslidzhen pid chas vyvchennia predmetiv pryrodnychomatematychnoho tsyklu [Using of mobile applications for educational research in the study of subjects in the mathematical cycle]. Kompiuter u shkoli ta simi, 2015. 3. 28 - 31 [in Ukrainian].

2. Osypchuk M. Mobilni tekhnolohii yak perspektyvnyi zasib navchannia fizyky [Mobile technology as a promising tool for teaching physics.]. Materialy II Mizhnarodnoi studentskoi naukovo-tekhnichnoi konferentsii «Pryrodnychi ta humanitarni nauky. Aktualni pytannia», 2019. p. 188-189. Available from: http://elartu.tntu.edu.ua/handle/lib/28402 [in Ukrainian].

3. Pudova S.S. Vykorystannia mobilnoho telefonu v navchalnomu protsesi [Using a mobile phone in the learning process]. Fizyko-matematychna osvita, 2018. (2): 97-101. [in Ukrainian].

4. Kuhn J., Vogt P. 2013. Smartphones as Experimental Tools: Different Methods to Determine the Gravitational Acceleration in Classroom Physics by Using Everyday
Devices. European Journal of Physics Education. 4, (1): 1627.

5. Yahenska H.V. Formuvannia doslidnytskykh umin uchniv 7-9 klasiv na urokakh ta $\mathrm{v}$ pozaklasnii roboti $\mathrm{z}$ biolohii [Formation of research skills of students of grades 7-9 in lessons and in extracurricular work in biology]. Lutsk, 2011. p.105 [in Ukrainian].

6. Vashchenko L.S. Rozvytok doslidnytskykh umin starshoklasnykiv v umovakh profilnoi shkoly [Development of research skills of high school students in the profile school]. Biolohiia i khimiia u ridnii shkoli, 2017. (3): 23-27 [in Ukrainian].

7. Kyrychuk O.V. Osnovy psykholohii [Fundamentals of psychology]. Romentsia. 4-te vyd., stereotyp. K.: Lybid, 1999. 632 [in Ukrainian].

8. Sechko O. Formyrovanye poznavatelnoho ynteresa uchashchykhsia $\mathrm{k}$ yzuchenyiu [The formation of cognitive interest of students in the study of chemistry]. 2016. P. 170 174. Available from: http://elib.bsu.by/bitstream/123456789/195201/1/Сечко_ФО 
РМИРОВА-

НИЕ\%20ПОЗНАВАТЕЛЬНОГО\%20ИНТЕРЕСА.pdf (Асcsesed on November 27, 2019) [in Russian].

9. Kakie datchiki ustanavlivajut $v$ smartfony $i$ zachem oni nuzhny. [What sensors are installed in smartphones and why are they needed]: Available from: https://chinareview.com.ua/6741-kakie-datchki-est-v-vashem-smartfonea-vy-dazhe-nedogadyvalist-ob-etom.html (Accsesed on November 28, 2019) [in Russian].

10. Gonzalez M A. Mobile Phones for Teaching Physics: Using Applications and Sensors. Second International Conference on Technological Ecosystems for Enhancing Multiculturality (TEEM'14). Salamanca, Spain, 2014. p. 349-356. Available from:

https://www.researchgate.net/publication/266327391_Mobile _Phones_for_Teaching_Physics_(Accsesed on December 22, 2019)

11. Scientific journal. Google Play. Available from: https://play.google.com/store/apps/details?id=com.google.and roid.apps.forscience. whistlepunk\&hl=uk (Accsesed on December 21, 2019)

12. Termometr+++. Google Play. Available from: https://play.google.com/store/apps/details?id=amuseworks.th ermometer (Accsesed on December 22, 2019)

13. Thermometer Smart Family. Google Play. Available from: https://play.google.com/store/apps/details?id=com.relsib.lesa. thermometerfamily (Accsesed on December 20, 2019)

14. Qualità dell'aria. Google Play. Available from: https://play.google.com/store/apps/details?id=ffz.it.airquality (Accsesed on December 20, 2019)

15. AWS Weather station home barometer and hygrometer. Google Play. Available from: https://play.google.com/store/apps/details?id=com.robobobo. apps.aws (Accsesed on December 20, 2019)

16. GoogleMaps. Google Play. Available from: https://play.google.com/store/search?q=GoogleMaps\&c=apps (Accsesed on November 10, 2019)

17. Birds of Ukraine. Google Play. Available from: https://play.google.com/store/apps/details?id=com.needapps. birds.birdua (Accsesed on November 10, 2019)
18. PlantNet Plant Identification. Google Play. Available from: https://play.google.com/store/apps/details?id=org.plantnet (Accsesed on November 12, 2019)

19. Flora Incognita - automated plant identification. Google Play. Available from: https://play.google.com/store/apps/details?id=com.floraincog nita.app.floraincognita (Accsesed on November 12, 2019)

20. INaturalist. Google Play. Available from: https://play.google.com/store/apps/details?id=org.inaturalist.a ndroid

21. Color Grab (color detection). Google Play. Available from: https://play.google.com/store/apps/details?id=com.loomatix.c olorgrab (Accsesed on December 23, 2019)

22. Smartphones in Science Teaching. The European Platform for Science Teachers. 2014. p. 21 - 24. Available from: https://www.science-on-

stage.de/download_unterrichtsmaterial/iStage_2_Smartphone s_in_Science_Teaching.pdf (Accsesed on October 25, 2019)

23. Chart Wizard. Google Play. Available from: https://play.google.com/store/apps/details?id=com.interclub.c harts (Accsesed on October 25, 2019)

24. Statistics Calculator Pro. Google Play. Available from: https: / /play.google.com/store/apps/details?id=com.cgollner.pro (Accsesed on October 26, 2019)

25. Kompleksne zabezpechennja navchaljnykh zakladiv Ukrajiny z dostavkoju - Diksi Edjukejshn. [Complex protection of primary mortgages in Ukraine with delivery Dixy Education]. Available from: https://dixi.education/shop/labquest-2/ (Accsesed on December 20, 2019)

26. School Chemistry Laboratory PASCO. Available from: http://inter-systems.com.ua/news/15582/ (Accsesed on December 20, 2019)

27. Globisens ${ }^{\circledR}$ labdisc practical laboratory experiments. Available from: https://www.tehnoinstyle.com.ua/reviews/obzoryelektroniki/globisens-labdisc-uvlekatelnye-laboratornyeeksperimenty (Accsesed on December 20, 2019) 